\title{
Effect of Pertalite - Methanol Blends on Performance and Exhaust Emission of a Four-stroke 125 CC Motorcycle Engine
}

\section{Wayan Sugita, Darwin Rio Budi Syaka, and Aziz Irianto Wahyudi}

Vocational Education Program of Mechanical Engineering, Faculty of Engineering, Universitas Negeri Jakarta

\section{Abstract}

The paper showed the effect of using Pertalite - methanol blend fuel on performances and exhaust emission of a four-stroke $125 \mathrm{cc}$ single cylinder engine. Two different blends of fuels, $100 \%$ Pertalite - 0\% methanol (MO) and 70\% Pertalite $-30 \%$ methanol (M30), were experimentally tested. The experiments were conducted with different engine speeds ranging from 5000 to $8500 \mathrm{rpm}$. Power, torque, brake specific fuel consumption (BSCF) and exhaust emissions were measured during the test. It was concluded that M30 blend generated the largest power, $5.28 \mathrm{~kW}$, at $7500 \mathrm{RPM}$. The

Corresponding Author:

I. Wayan Sugita

wayan-sugita@unj.ac.id

Received: 11 January 2019

Accepted: 14 February 2019

Published: 25 March 2019

Publishing services provided by Knowledge E

(c) I. Wayan Sugita et al. This article is distributed under the terms of the Creative Commons Attribution License, which permits unrestricted use and redistribution provided that the original author and source are credited.

Selection and Peer-review under the responsibility of the $3 \mathrm{rd}$ ICTVET 2018 Conference Committee. M30 fuel also produced the highest torque, $7.1 \mathrm{Nm}$, at 5500 RPM. For the specific fuel consumption, the best value of M30 fuel was $0.39 \mathrm{~kg} / \mathrm{kW} . \mathrm{h}$, at $7500 \mathrm{RPM}$, while the MO fuel has the best value at 7500 RPM that was $0.21 \mathrm{~kg} / \mathrm{kW}$.h. The M30 blend fuel decreased the emissions of carbon monoxide (CO), carbon dioxide (CO2), and hydrocarbon $(\mathrm{HC})$.

Keywords: Pertalite, methanol, power, torque, exhaust emission

\section{Introduction}

Fossil fuels are non-renewable fuels. Utilization of fossil fuels is very beneficial for human life such as for industrial activities, transportation and households. But the existence of fossil fuels is not always able to meet human needs. For this reason, it needs to add additives to decrease the fuels usage. Additive also improves the quality of fuels. One of the most important additive is methanol.

In some countries such as the United States and Brazil, M10 fuel (10\% Methanol and 90\% Gasoline) is sold as a substitute for pure gasoline. By using this fuel can reduce $\mathrm{HC}$ (Hydrocarbon) and CO (Carbon monoxide) emissions. Another advantage is reduce the gasoline usage by $10 \%$. Methanol is also used in some dual-fuel diesel engines.

Research on blend Premium gasoline - methanol fuel has been done to determine the performances of 4-stroke gasoline motors, according [8]. In this study, researchers 
used a mixture of Premium gasoline and methanol with the composition of M0, M5, M10, M15, M20, M25, and M30. The results of the study stated that the M15 fuel produced the highest engine output power. The power produced is $6.68 \mathrm{hp} / 7000 \mathrm{rpm}$, an increase of $12.7 \%$ compared to pure Premium fuel.

Other research on the effect of using a mixture of Premium gasoline and methanol on 4 stroke gasoline motor exhaust emissions, based on [4]. In this article, the fuel composition specimens used are M20, M40 and M60. Based on the test results, the M60 fuel shows the best exhaust emissions.

From these results on the mixture of gasoline and methanol on 4-stroke gasoline motor that already exists, it can be concluded that methanol has an effect on engine performances and exhaust emissions. However, the type of gasoline used is the Premium type. In this study, researchers used another type of gasoline, Pertalite. This study will look for engine performances and exhaust emissions.

\section{Method and Equipment}

Experiments were conducted on single cylinder, four stroke engines (Honda Vario Techno $125 \mathrm{cc}$ ). Testing is done by placing a motorcycle on a Computerized Dynamometer tool, and then the engine is turned on and tested in several engine rotation variants 5000, 5500, 6000, 6500, 7000, 7500, 8000 and 8500 rpm at constant load. Before data is taken, engine allowed running at idling speed for about 10 minutes. The test results listed on the test equipment monitor. This test is done repeatedly with two different blends of Pertalite fuel and methanol, MO and M30. The exhaust emission gas is recorded by exhaust gas analyzer KEG-500.

\subsection{Experimental set-up and procedure}

The motorcycle was checked and tuned-up according to standard specifications before tested. The specification of motorcycle is given in Table 1.

\subsection{Record of power and torque data}

The data of power and torque are recorded by computerized dynamometer. Motorcycle was installed with the front tire position on the wheel lock and the rear tire put in the roller so the motorcycle is balanced and in right position. The sensor is attached to the 
TABLE 1: Specification of Honda Vario Techno 125 eSP.

\begin{tabular}{l|l} 
Engine Type & $\begin{array}{l}\text { Four-stroke, Air cooled, single } \\
\text { cylinder, SI Engine }\end{array}$ \\
\hline Bore x Stroke & $52,4 \times 57,9 \mathrm{~mm}$ \\
\hline Stroke Volume & $124,8 \mathrm{cc}$ \\
\hline Max. Power & $8,3 \mathrm{~kW} / 8500 \mathrm{rpm}$ \\
\hline Max. Torque & $10,8 \mathrm{~N} . \mathrm{m} / 5000 \mathrm{rpm}$ \\
\hline Compression Ratio & $11: 1$ \\
\hline Fuel Supply System & Injection
\end{tabular}

spark plug cable so that rpm can be monitored on the computer. The engine turned on for approximately 10 minutes to reach the engine working temperature.

Turn on the computer to monitor dyno activity to determine power, torque, monitor brake temperature and room temperature during testing, room humidity, engine speed, actual vehicle speed, etc.

The blower or centrifugal fan blows directly to the engine to stabilize the engine temperature when tested. The gas pedal pulled from the zero throttles opening to full. This is done to see the difference in performances of each of the gas throttle openings. At each condition, the dyno engine pressure is hold to ensure the rpm on opening throttle is remains stable.

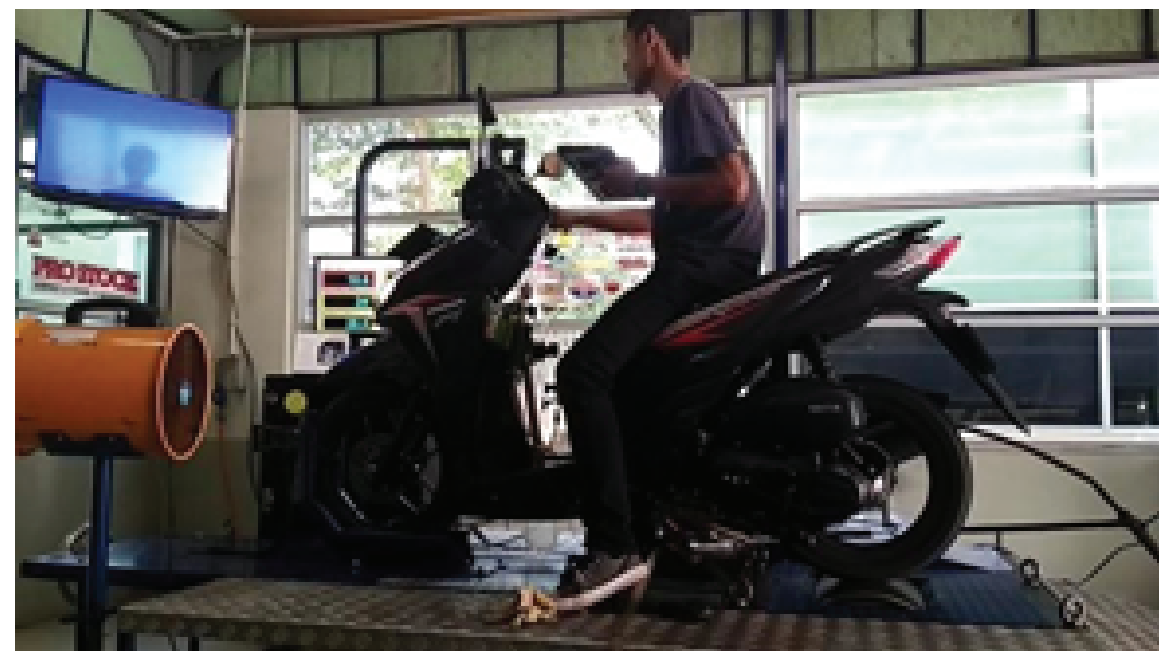

Figure 1: Computerized Dynamometer.

Computerized Dynamometer specification is given in Table 2. This procedure was conducted for both $\mathrm{MO}$ and $\mathrm{M} 30$ fuel blends. 
TABLE 2: Computerized Dynamometer specification.

\begin{tabular}{l|l} 
Max. Power & $940 \mathrm{HP}$ \\
\hline Max. Torque & $1254 \mathrm{lbs}-\mathrm{ft}$ \\
\hline Load Control System & Eddy Current \\
\hline Load Capacity & $4,500 \mathrm{~kg}$
\end{tabular}

\subsection{Record of brake specific fuel consumption (BSFC) data}

The fuel tank marked every $10 \mathrm{ml}$ of volume. The consumption of fuels tested from 5000 to $8500 \mathrm{rpm}$, same as power and torque conditions. At each pressure differences, the engine dynamometer is hold so the rpm on the throttle opening tested remains stable. Then the time is recorded to know how long the duration of time needed to spend as much as $10 \mathrm{ml}$ to find out fuel consumption.

The test is carried out for both data collection with $\mathrm{MO}$ and M30 blends fuel

\subsection{Record of exhaust gas emissions data}

Exhaust gas emissions are recorded by Exhaust Gas analyzer KEG-500. The specification of exhaust gas analyzer is given in Table 3.

TABLE 3: Exhaust Gas analyzer KEG-500 specification.

\begin{tabular}{l|l|l} 
Parameter & Range & Resolution \\
\hline O2 & $0-25 \%$ & $0.01 \%$ \\
CO & $0-9.99 \%$ & $0.1 \%$ \\
CO2 & $0-20 \%$ & $0.01 \%$ \\
HC & $0-10,000 \mathrm{ppm}$ & $1 \mathrm{ppm}$ \\
Nox & $0-5000 \mathrm{ppm}$ & $1 \mathrm{ppm}$ \\
AFR & $0.0-0.99$ & 0.01
\end{tabular}

\section{Result}

The results of the motor torque test with dynamometer using two different fuel samples of each variation of engine rotation for each fuel is obtained, as shown in Table 4 and Figure 2.

The results of the power test with dynamometer using two different fuel samples of each variation of engine rotation for each fuel is obtained, as shown in Table 5 and Figure 3. 
TABLE 4: Torque Comparison.

\begin{tabular}{|l|c|c|}
\hline \multicolumn{3}{|c}{ TORQUE (N.M) } \\
\hline RPM & MO & M30 \\
\hline 5000 & 3,6 & 4,82 \\
\hline 5500 & 5,31 & 7,1 \\
\hline 6000 & 5,03 & 6,11 \\
\hline 6500 & 4,26 & 4,76 \\
\hline 7000 & 6,14 & 6,47 \\
\hline 7500 & 7,02 & 6,81 \\
\hline 8000 & 6,58 & 5,85 \\
\hline 8500 & 6,39 & 5,44 \\
\hline MAX & $\mathbf{7 , 0 2}$ & $\mathbf{7 , 1}$ \\
\hline
\end{tabular}

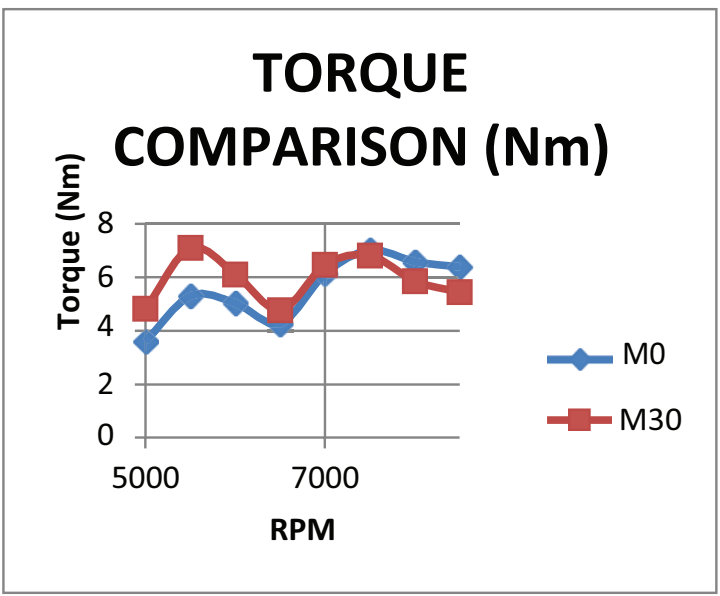

Figure 2: Torque comparison between two fuel blends on various rpm.

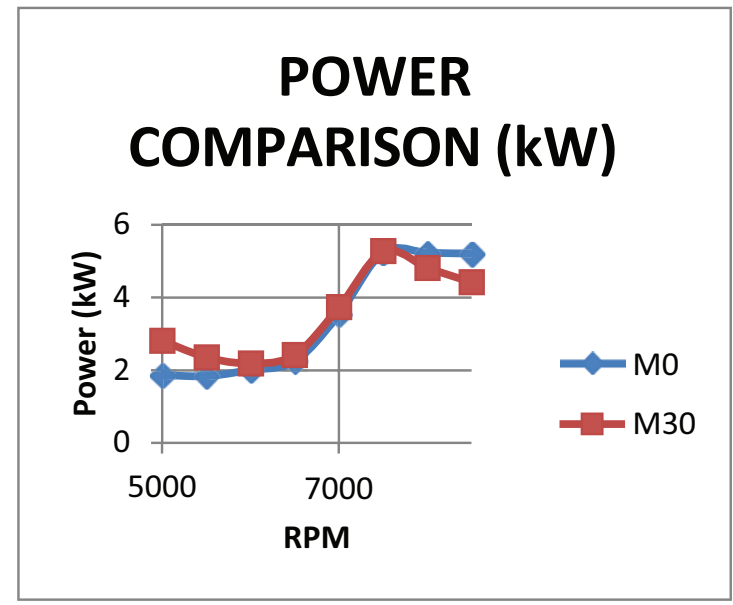

Figure 3: Power comparison between two fuel blends on various rpm.

The results of the power test with dynamometer using two different fuel samples of each variation of engine rotation for each fuel is obtained, as shown in Table 6 and Figure 4. 
TABLE 5: Power Comparison.

\begin{tabular}{|l|c|c|}
\multicolumn{3}{|c}{ POWER (kW) } \\
\hline RPM & MO & M30 \\
\hline 5000 & 1,87 & 2,82 \\
\hline 5500 & 1,84 & 2,36 \\
\hline 6000 & 2,01 & 2,19 \\
\hline 6500 & 2,24 & 2,42 \\
\hline 7000 & 3,54 & 3,74 \\
\hline 7500 & 5,25 & 5,28 \\
\hline 8000 & 5,22 & 4,82 \\
\hline 8500 & 5,2 & 4,42 \\
\hline MAX & $\mathbf{5 , 2 5}$ & $\mathbf{5 , 2 8}$ \\
\hline
\end{tabular}

\section{BSFC COMPARISON} (kg/kW.hour)

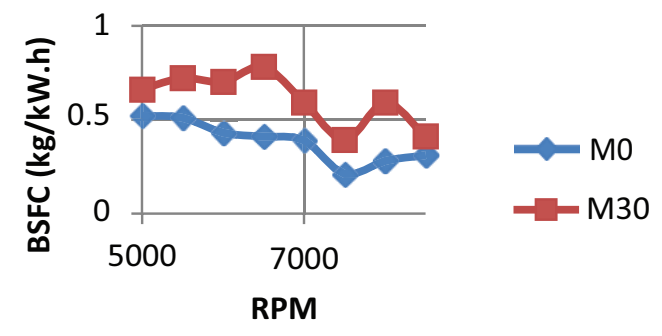

Figure 4: BSFC comparison between two fuel blends on various rpm.

TABLE 6: Brake-specific fuel consumption (BSFC) comparison.

\begin{tabular}{|l|c|c|}
\multicolumn{3}{|c|}{ BSFC (kg/kW·hour) } \\
\hline RPM & MO & M30 \\
\hline 5000 & 0,52 & 0,66 \\
\hline 5500 & 0,51 & 0,72 \\
\hline 6000 & 0,43 & 0,7 \\
\hline 6500 & 0,41 & 0,78 \\
\hline 7000 & 0,39 & 0,59 \\
\hline 7500 & 0,21 & 0,39 \\
\hline 8000 & 0,28 & 0,59 \\
\hline 8500 & 0,31 & 0,41 \\
\hline MAX & $\mathbf{0 , 2 1}$ & $\mathbf{0 , 3 9}$ \\
\hline
\end{tabular}

\section{Discussion}

Based on the graph in Figure 3, the torque produced by a motor that used M30 more stable and higher than MO. The power produced using M30 is bigger than MO as 


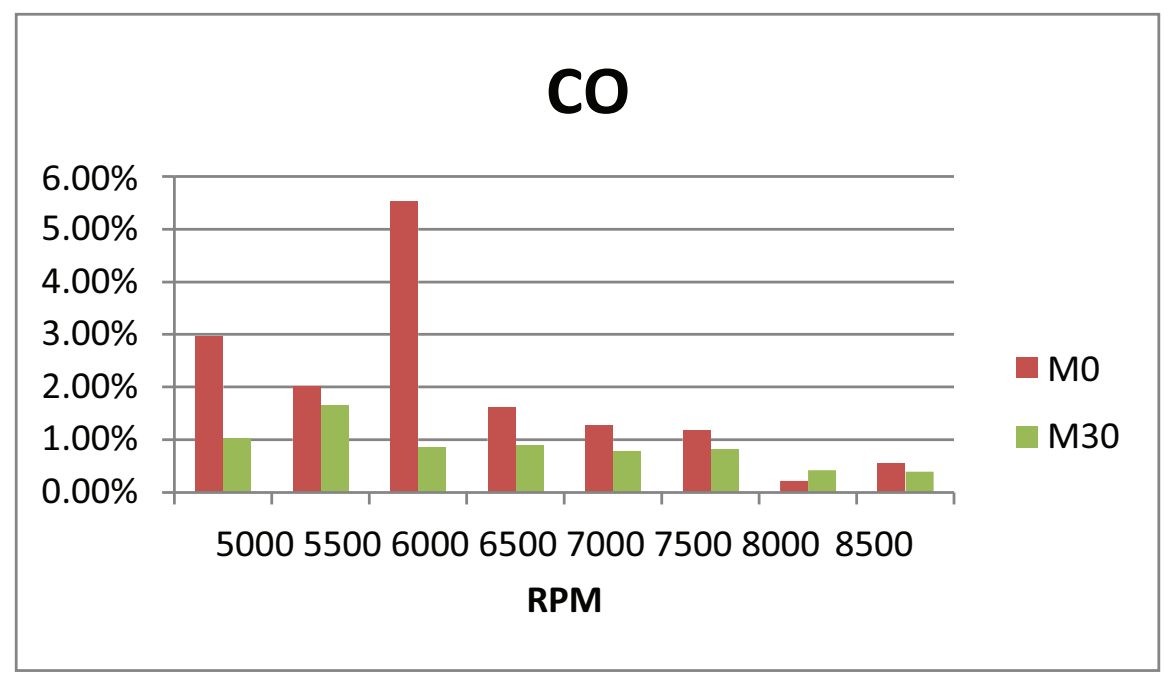

Figure 5: Comparison of $\mathrm{CO}$ gas levels between two fuel blends on various rpm.

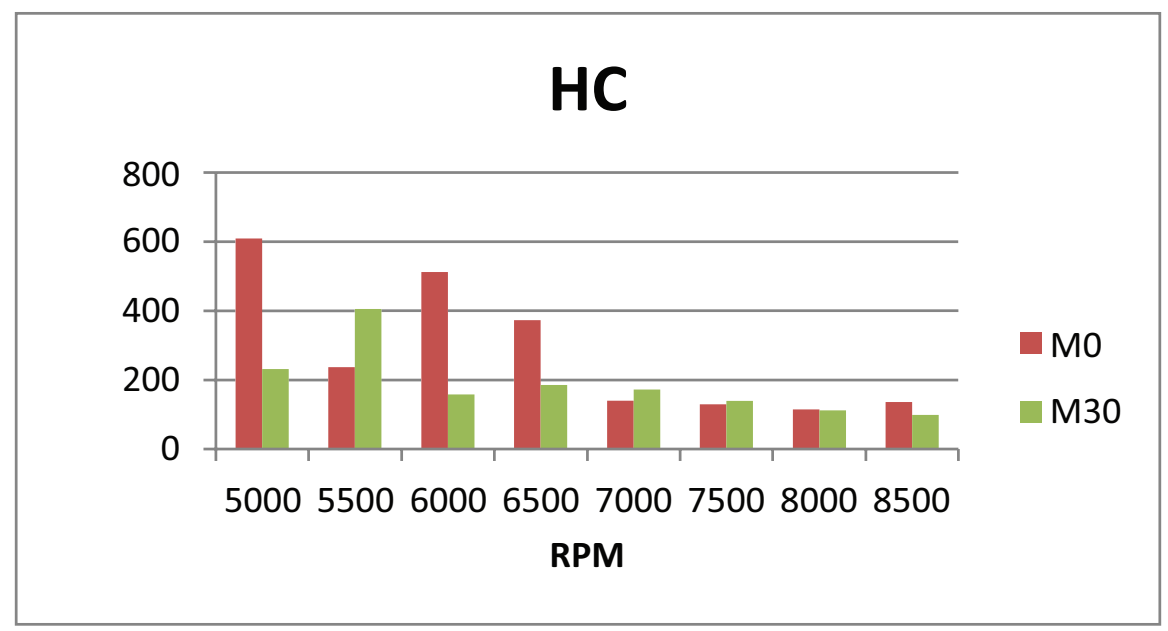

Figure 6: Comparison of $\mathrm{HC}$ gas levels between two fuel blends on various rpm.

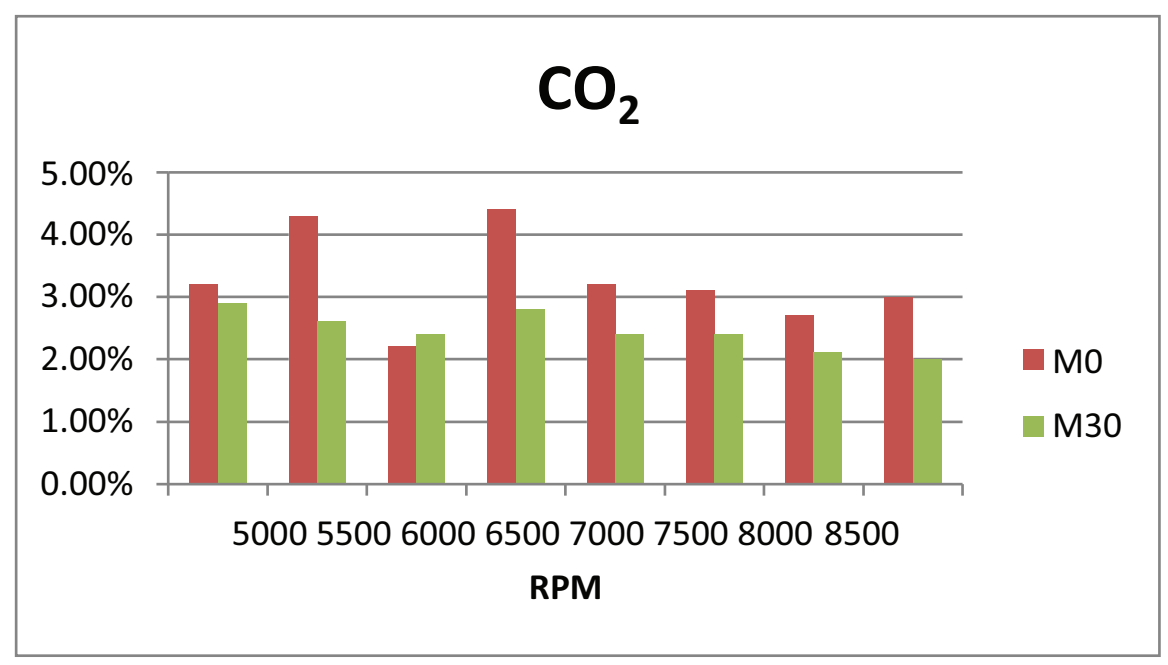

Figure 7: Comparison of $\mathrm{CO} 2$ gas levels between two fuel blends on various rpm. 
shown in Figure 4. These related to the value of the RON (Research Octane Number) on methanol which is higher than Pertalite gasoline. The value of RON methanol is 106, while Pertalite gasoline is only 90 . The greater the RON value, the more perfect the combustion, so the motor torque and power produced are greater. The maximum torque for M30 is 7,1 Nm at 5500 RPM, while for MO is 7,02 Nm at 7500 RPM. The maximum power for M30 is 5,28 kW at 7500 RPM, while for MO is 5,25 kW at 7500 RPM.

The value of BSFC produced by M30 looks higher for each rpm than produced by MO. This indicates the consumption of motor fuel that uses MO more efficient than M30. The minimum recorded BSFC value is $0.39 \mathrm{~kg} / \mathrm{kW}$.hour for $\mathrm{M} 30$, while for $\mathrm{MO}$ fuel is $0.21 \mathrm{~kg} / \mathrm{kW}$.hour. The minimum BSFC value difference recorded is $0.2 \mathrm{~kg} / \mathrm{kW}$.hour. The figure is not far adrift when compared to the reduction in consumption of Pertalite gasoline which is reduced by $30 \%$.

Based on these data of Figure 5, MO produced more $\mathrm{CO}$ gas than M30 for each different rpm. Only at 8000 RPM engine speed which shows the level of $\mathrm{CO}$ gas are produced by M30 more than M0. This is in accordance with the theory of combustion reactions between the two fuels.

Based on Figure 6, MO produced more HC gas than MO. Only at 7000 and 7500 RPM show that the level of $\mathrm{HC}$ produced by M30 more than MO.

The level of $\mathrm{CO} 2$ produced $\mathrm{MO}$ fuel is more than $\mathrm{M} 30$ fuel for each different engine speeds. Only at 6000 RPM shows the level of $\mathrm{CO} 2$ gas produced by M30 more than MO.

\section{Conclusion}

The M30 blend generated the largest power, $5.28 \mathrm{~kW}$, at 7500 RPM. The M30 fuel also produced the highest torque, $7.1 \mathrm{Nm}$, at 5500 RPM. For the specific fuel consumption, the best value of M30 fuel was $0.39 \mathrm{~kg} / \mathrm{kW}$.h, at $7500 \mathrm{RPM}$, while the MO fuel has the best value at 7500 RPM that was $0.21 \mathrm{~kg} / \mathrm{kW}$.h. The effect of the addition 30\% methanol to Pertalite fuel as an additive can increase the power value and torque of the gasoline motor. However, it is also makes fuel consumption increase. Generally, the M30 blend fuel decreased the emissions of carbon monoxide (CO), carbon dioxide (CO2) and hydrocarbon $(\mathrm{HC})$. 


\section{References}

[1] Arismunandar, Wiranto. (1988). Penggerak Mula Motor Bakar Piston. Bandung: Institut Teknologi Bandung.

[2] Anonim. (2013). Buku Pedoman Perbaikan Mekanika Mesin. Jakarta: PT. Astra Daihatsu Motor.

[3] Anonim. (2010). New Step 1 Training Manual. Jakarta: Toyota Motor.

[4] Arijanto, Gunawan D. (2006). Pengujian Campuran Bahan Bakar Premium-Methanol Pada Mesin Sepeda Motor 4 Langkah Terhadap Emisi Gas Buang. Jurnal ROTASI, 8 No. 2, pp. 19 - 29.

[5] Halderman, James D. (2012). Automotive Technology: Principles, Diagnosis, and Service. New Jersey, US: Pearson Education, Inc.

[6] Kristanto, Philip. (2015). MOTOR BAKAR TORAK (Teori dan Aplikasinya). Yogyakarta: ANDI.

[7] Landalv, Ingvar. (2017). Methanol As A Renewable Fuel - A Knowledge Synthesis. Lulea: SWE: The Swedish Knowledge Centre For Renewable Transportation Fuels.

[8] Nugroho, Arif S. (2015). Pengaruh Campuran Methanol Terhadap Prestasi Mesin. SNATIF ke-2 FT - Universitas Muria Kudus. Kudus: Universitas Muria Kudus.

[9] Pulkrabek, Willard W. (1997). Engineering Fundamentals of the Internal Combustion Engine. New Jersey: Prentice-Hall, Inc.

[10] Heywood J.B. (1988). Internal Combustion Engine Fundamentals. USA, New York: McGraw-Hill.

[11] Brinkman, N.D., Ecklund, E.E., Nichols, R.J. (1990). Fuel Methanol - A Decade of Progress. Society of Automotive Engineers, Inc. ISBN 1-56091-011-9., 60.

[12] Chen, H., Yang, L., Zhang, P.-H., Harrison, A. (2014). The controversial fuel methanol strategy in China and its evaluation (2014) Energy Strategy Reviews, 4, pp. 28-33.

[13] Jennings, J.R. and Short, G.D. (2016). Enhanced fuel and method of producing enhanced fuel for operating internal combustion engine.

[14] Yasar, A. (2010). Effects of alcohol-gasoline blends on exhaust and noise emissions in small scale generators. Metalurgija, Vol. 49, No. 4, pp. 335-338.

[15] Liu Shenghua, Eddy R. Cuty Clemente, Hu Tiegang, Wei Yanjv.(2007). Study of spark ignition engine fueled with methanol/gasoline fuel blends. Applied Thermal Engineering 27 (2007) 1904-1910.

[16] S. Babazadeh Shayan, S. M. Seyedpour, F. Ommi, S. H. Moosavy and M. Alizadeh. (2011). The impact of Methanol-Gasoline Fuel Blends on the Performance and 
Exhaust Emissions of an SI Engine. International Journal of Automotive Engineering Vol. 1, Number 3, July 2011. 